\title{
ANALISIS FAKTOR-FAKTOR KEBISINGAN KOMPLEK PERGURUAN MUHAMMADIYAH DI KOTA PEKANBARU
}

\author{
Rizo Wirman Hidayat ${ }^{1}$, Noni Febriani, ST $^{2}$, Amin Ridhoni, ST $^{3}$ \\ Program Studi Fisika, FMIPA dan Kesehatan, Universitas Muhammadiyah Riau, \\ Jl. KH. Ahmad Dahlan No. 88 Sukajadi, Pekanbaru, 28124, Indonesia \\ E-mail: rizo@saputra@gmail.com
}

\begin{abstract}
ABSTRAK
Dalam proses belajar mengajar, konsentrasi menjadi salah satu faktor utama yang mempengaruhi hasil pembelajaran seperti penyerapan materi pelajaran. Konsentrasi menjadi terganggu jika terjadi gangguan akibat faktor-faktor lingkungan, salah satunya adalah kebisingan. Tujuan dari penelitian ini adalah memetakan tingkat kebisingan di Komplek Perguruan Muhammadiyah Kota Pekanbaru dan mengetahui faktor-faktor apa yang mempengaruhi kebisingan. Metode yang digunakan dalam penelitian ini adalah penelitian survei yang bersifat deskriptif yaitu untuk mengetahui gambaran tentang tingkat kebisingan pada Komplek Perguruan Muhammadiyah di Kota Pekanbaru dengan melakukan pengukuran tingkat kebisingan. Hasil penelitian menunjukkan bahwa Komplek Perguruan Muhammadiyah di Kota Pekanbaru memiliki tingkat kebisingan sebesar $69 \mathrm{~dB}$ (A) pada jam belajar dan 54,1 dB (A) pada malam hari. Hasil dari pemetaan intensitas kebisingan pada jam belajar menunjukan tingkat kebisingan tertinggi menyebar dari timur menuju ke barat lokasi penelitian, sedangkan pada malam hari menunjukan tingkat kebisingan tertinggi menyebar dari tenggara menuju ke barat lokasi penelitian dan pusat kebisingan berasal dari jalan KH. Ahmad Dahlan.
\end{abstract}

Kata kunci: Noise, Mapping

\section{PENDAHULUAN Latar Belakang}

Sekolah merupakan suatu institusi yang dibutuhkan oleh masyarakat Indonesia sebagai salah satu upaya meningkatkan sumber daya manusia, dan juga merupakan lembaga yang berfungsi untuk menggali, mengembangkan dan mewariskan nilai-nilai kepada generasi penerus berikutnya, karena itu sekolah merupakan produsen yang melahirkan tenaga pemikir dan pelopor pembangunan bangsa dan negara yang akan mengabdikan ilmu pengetahuan dan keterampilannya di masyarakat.

Menurut J.Gulbert yang dikutip dari Syahrial (2001) mengelompokan faktor-faktor yeng mempengaruhi proses belajar kedalam empat besar, yaitu faktor materi, lingkungan, instrumen, dan faktor individu subyek belajar. Faktor materi meliputi hal yang dipelajari. Faktor lingkungan dikelompokan pada dua kelompok yaitu, lingkungan fisik yang meliputi suhu, kelembaban udara, pencahayaan dan kebisingan, sedangkan faktor lingkungan yang kedua adalah lingkungan sosial.
Komplek Perguruan Muhammadiyah Kota Pekanbaru terletak di jalan KH. Ahmad Dahlan No. 90 yang berbatasan dengan jalan Bangau di sebelah Utara, Jalan Tiung di sebelah Barat, di sebelah Selatan adalah kampus Universitas Islam Negeri Sultan Syarif Kasim (UIN SUSKA) dan di sebelah Timur adalah jalan KH.Ahmad Dahlan. Dengan lokasi tersebut maka kebisingan tidak dapat dihindari seperti dari transportasi di jalan, aktifitas gedung dan aktifitas kegiatan belajar mengajar.

\section{Penelitian Terdahulu}

Pada penelitian sebelumnya yang dilakukan oleh Syafridah (2005), hasil pengukuran tingkat kebisingan di ruang kelas SD Negeri yang berada di tepi jalan di Kecamatan Medan Perjuangan menunjukan bahwa dari 13 SD Negeri tingkat kebisingan seluruh ruang kelas dan perpustakaan tidak ada yang memenuhi syarat kesehatan sesuai Buku Tingkat Kebisingan (BTK) yaitu semuanya $>55 \mathrm{~dB}$ (A). Studi lain dari Shield dan Dockrell (2003) dalam Justian (2012) membuktikan bahwa di London, kebisingan ekternal dapat memberikan dampak 
negatif pada standar penentuan skor dari ujian di sekolah dasar di London. Studi ini menunjukkan bahwa kebisingan ekternal mempengaruhi kecakapan berbicara di dalam kelas dan memiliki dampak yang besar dalam nilai ujian.

Sehubungan dengan penelitian sebelumnya, peneliti mengedarkan angket kuesioner untuk mengetahui keluhan pada peserta didik yang berada di Komplek Perguruan Muhammadiyah Kota Pekanbaru yang memiliki kesamaan lokasi dari penelitian sebelumnya dan merupakan satu kawasan komplek pendidikan. Hasil dari angket kuesioner di atas mengenai hubungan tingkat kebisingan dan keluhan pada peserta didik di SMA Muhammadiyah 1 Pekanbaru yang dilakukan pada 21-22 November 2013 yang menunjukkan hasil bahwa dari 353 responden, $64 \%$ responden terganggu akibat kebisingan dan $57 \%$ responden mengalami gangguan komunikasi. Berdasarkan hal tersebut maka perlu dilakukan penelitian terhadap analisis faktor-faktor kebisingan komplek Perguruan Muhammadiyah Kota Pekanbaru.

\section{Tujuan Penelitian}

Tujuan penelitian adalah memetakan tingkat kebisingan di Komplek Perguruan Muhammadiyah Kota Pekanbaru dan mengetahui faktor-faktor apa yang mempengaruhi kebisingan.

\section{Manfaat Penelitian}

Manfaat dilakukan penelitian ini diharapkan memberikan informasi yang mempengaruhi tingkat kebisingan dan tingkat keyamanan peserta didik dalam memperoleh materi pelajaran sehingga kedepannya dapat dilakukan langkah nyata untuk mengurangi tingkat kebisingan untuk kemajuan hasil pendidikan peserta didik.

\section{METODOLOGI PENELITIAN}

\section{Landasan Teori}

Penetapan Lokasi dan Kebutuhan Ruang Belajar Untuk Sekolah Menengah Atas (SMA)Lokasi sekolah dapat digabungkan dalam satu komplek dengan Sekolah Menengah Pertama (SMP) dan Sekolah Menengah Atas (SMA). Sebagai mana SMA Muhammadiyah 1 Pekanbaru berada dalam Komplek Perguruan
Muhammadiyah Kota Pekanbaru yang terdiri dari SMP Muhammadiyah 1 Pekanbaru dan SMK Muhammadiyah 2 Pekanbaru. Peta lokasi Perguruan Muhammadiyah Kota Pekanbaru dapat dilihat pada Gambar 1.Untuk menentukan kebutuhan ruang belajar SMA perlu dihitung:

a. Berapa jumlah anak usia SMA pada 5 (lima) tahun yang akan datang.

b. Berapa anak usia SMA yang ada dalam lingkungan pemukiman.

c. Berapa unit ruang belajar yang sudah tersedia dan berapa daya tampungnya.

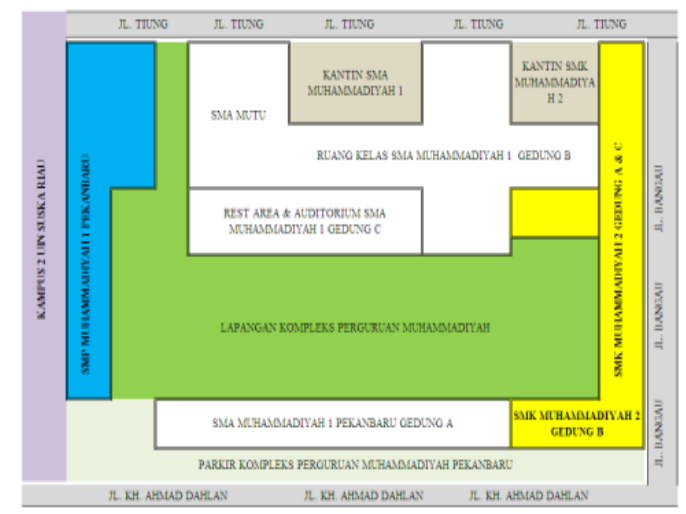

Gambar 1. Komplek Perguruan

Muhammadiyah Pekanbaru.

\section{Pengertian Kebisingan}

Menurut Notoatmodjo (1997), bising atau kebisingan adalah bunyi yang tidak kita inginkan atau kehendaki dalam kehidupan sehari-hari, termasuk bunyi yang berasal dari tempat kerja.

Kebisingan adalah bunyi yang tidak diinginkan dari usaha atau kegiatan dalam tingkat dan waktu tertentu yang dapat menimbulkan gangguan kesehatan manusia dan kenyamanan lingkungan (Kep MENLH No: KEP-48/MENLH/II/1996).

Menurut Leslie (1993), kebisingan adalah tiap bunyi yang tidak dinginkan oleh penerima. Sehingga tiap bunyi yang mengalihkan perhatian, mengganggu, atau berbahaya bagi kegiatan sehari-hari (kerja, istirahat, hiburan atau belajar) dianggap sebagai bising.

Sedangkan menurut Permenkes No:781/MENKES/Per/IX/1987 kebisingan adalah terjadi bunyi yang tidak di kehendaki 
sehingga mengganggu atau membahayakan kesehatan.

Jadi Kebisingan dapat diartikan sebagai bunyi atau suara yang timbul akibat dari suatu aktifitas pada waktu tertentu yang tidak diinginkan dan dapat menimbulkan gangguan kesehatan manusia dan kenyamanan lingkungan.

\section{Bunyi dan Mekanisme Kebisingan}

Bunyi dikatakan sebagai sensasi pendengaran yang lewat telinga dan timbul karena penyimpangan tekanan udara. Penyimpangan ini biasanya disebabkan oleh beberapa benda yang bergetar, misalnya dawai gitar yang dipetik atau garpu tala yang dipukul (Gambar 2). Sewaktu fluktuasi tekanan udara ini membentur gendang pendengaran (membrane Tympani) dari telinga kita maka membran ini akan bergetar sebagai jawaban pada fluktuasi tekanan udara. Getaran ini melalui saluran dan proses tertentu akan sampai di otak kita dimana hal ini diinterpretasikan sebagai suara.

Suara bising akan dapat terjadi apabila ada 3 (tiga) hal yaitu: sumber bising, media atau udara, dan penerima. Dari sumber bising, suara akan merambat melalui udara dalam bentuk gelombang sampai suara tersebut diterima oleh pendengar/ penerima. Kebisingan tidak akan terjadi tanpa adanya media/ udara. Pengurangan kebisingan dapat dilakukan dengan jalan pengunaan isolasi/ isolator antara sumber dan penerima.

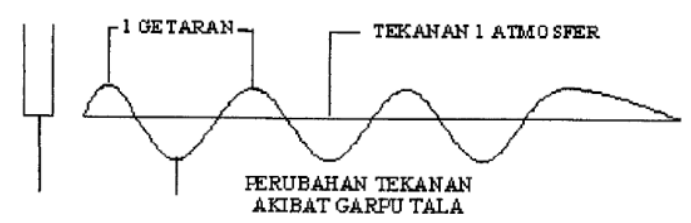

Gambar 2. Garpu Tala yang dipukul menghasilkan perubahan tekanan di udara karena getarannya dan menghasilkan bunyi.

(Sumber: Leslie, 1993)

Tingkat tekanan bunyi minimum yang mampu membangkitkan sensasi pendengaran di telinga disebut ambang kemampuan di dengar. Bila tekanan bunyi ditambah dan bunyi menjadi lebih keras akhirnya ia mencapai suatu tingkat dimana sensasi pendengaran menjadi tidak nyaman. Intensitas suara rendah yang masih dapat didengar oleh manusia (ambang pendengaran ideal) adalah $20 \mu \mathrm{Pa}$ (micro paskal). Intenssitas suara inilah yang dianggap sebagai referensi artinya setiap tekanan suara tertentu harus dibandingkan dengan tekanan suara ini.

Perbandingan di antara tekanan suara tertentu dengan tekanan suara refrensi disebut tingkat tekanan suara (sound pressure level $S P L)$. Hubungan ini secara matematis dinyatakan sebagai berikut:

$$
S P L(d B)=10 \log \frac{p_{1}^{2}}{p_{0}^{2}}
$$

Dengan,

$\mathrm{P}_{1}=$ tekanan suara dalam newton per meter kuadrat

$\mathrm{P}_{0}=$ referensi tekanan suara $\left(0,00002 \mathrm{~N} / \mathrm{m}^{2} /\right.$ $20 \mu \mathrm{Pa})$

$$
\mathrm{dB}=\text { decibel (satuan tingkat tekanan udara) }
$$

Perhitungan ini dapat disederhanakan menjadi

$$
S P L(d B)=20 \log \frac{p_{1}}{p_{a}}
$$

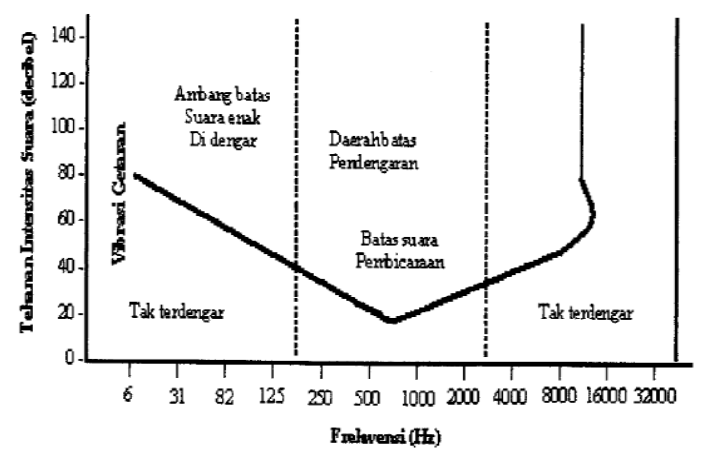

Gambar 3. Beberapa frekuensi yang berkaitan dengan pendengaran manusia.

(Sumber: DepKes RI, 1991)

Berarti ambang pendengaran ideal tekanan suara sebesar $20 \mu \mathrm{Pa}$ dan inilah yang sama dengan $0 \mathrm{~dB}$, dengan demikian $0 \mathrm{~dB}$ tidak berarti ada suara.

Lebar respon telinga manusia diantara $0 \mathrm{~dB}$ - $140 \mathrm{~dB}$ yang dapat di dengar. Dan batas intensitas suara tinggi adalah $140 \mathrm{~dB}$ dimana untuk mendengar suara itu sudah timbul perasaan sakit pada alat pendengaran. Hal inilah yang kemudian menimbulkan masalah kesehatan akibat tekanan suara yang tinggi. Namun 
jangkauan frekwensi audio orang berbeda menurut umur tersebut. Dengan bertambahnya umur batas jangkauan frekwensi audio orang akan turun atau berkurang (Leslie, 1993).

\section{Sumber-Sumber Bising}

Sumber bising adalah suatu hal yang tidak dapat diragukan lagi sebagai asal atau aktifitas yang mengasilkan suara bising yang merusak pendengaran baik bersifat sementara ataupun permanen. Sumber bising utama dalam pengendalian bising lingkungan diklasifikasikan dalam kelompok:

1. Bising interior yaitu bising yang berasal dari manusia, alat-alat rumah tangga, mesin dan aktifitas di dalam ruangan atau gedung.

2. Bising luar yaitu bising yang di kategorikan berasal dari aktifitas di luar ruangan seperti transportasi udara, bus, mobil sepeda motor, transportasi air, kereta api, dan bising yang berasal dari industri. Untuk bising transportasi yang terpenting adalah makin cepat kendengaran akan semakin keras suara bising yang dihasilkan (Leslie, 1993).

\section{Metode Pengukuran}

Metode Sederhana

Dengan sebuah sound level meter bisa di ukur tingkat tekanan bunyi $\mathrm{dB}(\mathrm{A})$ selama 10 (sepuluh) menit untuk tiap pengukuran. Pembacaan dapat dilakukan setiap 5 (lima) detik. Alat sound level meter dapat digunakan untuk pengukuran:

1. Kebisingan industri dan lingkungan.

2. Analisa frekwensi dari sumber suara.

Range dB yang dapat dipilih: $40-110 \mathrm{~dB}, 50$ $-120 \mathrm{~dB}, 60-130 \mathrm{~dB}$.

Metode Langsung

Dengan sebuah integrating Sound Level Meter yang mempunyai fasilitas pengukuran LTM5, yaitu Leq dengan waktu ukur setiap 5 (lima) detik, dilakukan pengukuran selama 10 (sepuluh) menit.

Waktu pengukuran dilakukan selama 24 jam (LSM) dengan cara pada siang hari tingkat aktivitas yang paling tinggi selama 16 jam (LS) pada selang waktu 06.00 - 22.00 dan aktivitas malam hari selama 8 jam (LM) pada selang waktu $22.00-06.00$.
Setiap pengukuran harus dapat mewakili selang waktu tertentu dengan menetapkan paling sedikit 4 (empat) waktu pengukuran pada siang hari dan pada malam hari paling sedikit 3 (tiga) waktu pengukuran, sebagai contoh:

1. L1 diambil pada jam 07.00, mewakili jam $06.00-09.00$

2. L2 diambil pada jam 10.00 , mewakili jam $09.00-11.00$

3. L3 diambil pada jam 15.00, mewakili jam $14.00-17.00$

4. L4 diambil pada jam 20.00, mewakili jam $17.00-22.00$

5. L5 diambil pada jam 23.00, mewakili jam $22.00-24.00$

6. L6 diambil pada jam 01.00, mewakili jam $24.00-03.00$

7. L7 diambil pada jam 04.00, mewakili jam $03.00-06.00$

Untuk mengetahui tingkat kebisingan ekivalen dengan waktu pengukuran setiap 5 detik selama 10 menit yang terjadi maka 120 data tingkat kebisingan harus diolah menurut KEP-48/MENLH/11/1996 menjadi 1 data tingkat kebisingan ekivalen yang di ukur tiap 5 detik selama 10 menit.

Untuk mengetahui nilai $\mathrm{L}_{\text {TM5 }}$ digunakan rumus sebagai berikut:

$\mathrm{L}_{\text {TM5 }}=10 \log 1 / 600\left\{5.10^{0,1 \mathrm{~L} 1}+5.10^{0,1 \mathrm{~L} 2}+\ldots\right.$ $\left.+5 \cdot 10^{0,1 \mathrm{~L} 120}\right\}$

Untuk data dari waktu pengambilan interval 1 4 (siang hari)

$\mathrm{L}_{\mathrm{S}}=10 \log 1 / 16\left\{\mathrm{~T} 1 \cdot 10^{0,1 \mathrm{~L} 1}+\ldots+\mathrm{T} 4 \cdot 10^{0,1 \mathrm{~L} 4}\right\}$ $\mathrm{dB}(\mathrm{A})$

Untuk data dari waktu pengambilan interval 5 7 (malam hari)

$\mathrm{L}_{\mathrm{M}}=10 \log 1 / 8\left\{\mathrm{~T} 5 \cdot 10^{0,1 \mathrm{~L} 1}+\ldots+\mathrm{T} 7 \cdot 10^{0,1 \mathrm{~L} 4}\right\}$ $\mathrm{dB}(\mathrm{A})$

Untuk mengetahui apakah tingkat kebisingan sudah melampaui baku tingkat kebisingan maka perlu dicari nilai $\mathrm{L}_{\mathrm{SM}}$. $\mathrm{L}_{\mathrm{SM}}$ dihitung dengan rumus:

$\mathrm{L}_{\mathrm{SM}}=10 \log 1 / 24\left\{16 \cdot 10^{0,1 \mathrm{LS}}+8 \cdot 10^{0,1 \mathrm{LM}+5}\right\} \mathrm{dB}$ (A) (2.6)

Keterangan:

Leq: Equivalent Continous Noise Level atau Tingkat Kebisingan sinambung Setara ialah 
tingkat kebisingan dari kebisingan yang berubah-ubah (fluktuatif) selama waktu tertentu, yang setara dengan tingkat kebisingan dari kebisingan yang (steady) pada selang waktu yang sama.

L $\quad$ : Leq dengan waktu sampling tiap 5 (lima) detik

$\mathrm{L}_{\mathrm{S}}$ : Leq selama siang hari

$\mathrm{L}_{\mathrm{M}}$ : Leq selama malam hari

$\mathrm{L}_{S M}$ : Leq selama siang dan malam hari

Setelah mendapatkan nilai $\mathrm{L}_{\mathrm{SM}}$ selanjutnya dapat dilakukan evaluasi. Evaluasi dilakukan dengan membandingkan nilai $\mathrm{L}_{\mathrm{SM}}$ dengan baku tingkat kebisingan yang ditetapkan dengan toleransi $+3 \mathrm{~dB}$ (A). Rumus diatas dapat dimodifikasi disesuaikan dengan interval dan waktu sampling.

Untuk mendapatkan nilai tingkat kebisingan di sekitar (tegak lurus) titik sampling dengan radius tertentu (line source) digunakan rumus:

$$
\mathrm{L}_{\mathrm{dx}}=\mathrm{L} 1-10 \log \left(\mathrm{x} / \mathrm{x}_{0}\right) \ldots \ldots \ldots
$$

Dimana:

$\mathrm{L}_{\mathrm{dx}}$ : Tingkat kebisingan pada jarak $\mathrm{x}$

L1 : $\mathrm{L}_{\mathrm{SM}}$ ekivalen 4 hari

$X$ : jarak titik yang diukur tingkat kebisingannya dari sumber bising (tengah jalan)

$\mathrm{x}_{0} \quad$ : jarak titik sampling dari sumber bising (tengah jalan)

Selain menggunakan Sound Level Meter, pengukuran kebisingan juga dapat dilakukan dengan alat lain seperti Noise Logging Dosimeter. (Kementerian Lingkungan Hidup, 2002).

\section{Perhitungan Jumlah Kendaraan}

Penelitian dilakukan dengan mengambil data secara langsung pada titik sampling yang telah ditentukan sebelumnya. Perhitungan data jumlah kendaraan dilakukan dengan menggunakan counter. Jenis kendaraan akan dibedakan menjadi 2 jenis, yaitu kendaraan roda dua dan kendaraan roda $>2$. Dari perhitungan yang dilakukan akan didapatkan jumlah untuk masing-masing jenis kendaraan.

\section{Ruang Lingkup Penelitian}

Waktu dan Tempat Penelitian

Waktu Penelitian dilakukan pada bulan Agustus 2014. Pengambilan data dilakukan pada waktu jam belajar pukul 09:00 WIB dan pada waktu malam hari pukul 21:30 WIB.

Lokasi penelitian adalah Komplek Perguruan Muhammadiyah Kota Pekanbaru berada di jalan KH. Ahmad Dahlan No. 90 Kelurahan Kampug Melayu, Kecamatan Sukajadi Kota Pekanbaru Propinsi Riau. Komplek Perguruan Muhammadiyah Kota Pekanbaru terdiri dari SMA Muhammadiyah 1 Pekanbaru, SMP Muhammadiyah 1 Pekanbaru dan SMK Muhammadiyah 2 Pekanbaru. Pengolahan data dan analisis dilakukan di Laboratorium Fisika Terpadu Fakultas MIPA dan Kesehatan Kampus 2 UMRI, Jalan Nangka Pekanbaru.

Tabel 1. Alat dan Bahan Penelitian

\begin{tabular}{|c|c|c|}
\hline No & Alat dan Bahan & Fungsi \\
\hline 1 & $\begin{array}{c}\text { Smartphone Samsung } \\
\text { Galaxy Core Duos } \\
\text { i8262 }\end{array}$ & $\begin{array}{l}\text { Telepon pintar } \\
\text { genggam. }\end{array}$ \\
\hline 2 & $\begin{array}{c}\text { Aplikasi Noise Meter } \\
2.5 .\end{array}$ & $\begin{array}{l}\text { Mengukur } \\
\text { Tingkat } \\
\text { Kebisingan. }\end{array}$ \\
\hline 3 & $\begin{array}{l}\text { Smartphone Samsung } \\
\text { Galaxy Fame Gts6810 }\end{array}$ & $\begin{array}{l}\text { Telepon pintar } \\
\text { genggam. }\end{array}$ \\
\hline 4 & Aplikasi Clik Counter & $\begin{array}{l}\text { Menghitung } \\
\text { manual secara } \\
\text { digital. }\end{array}$ \\
\hline 5 & $\begin{array}{l}\text { Aplikasi Google } \\
\text { Earth dan } \\
\text { Aplikasi Surfer } 9\end{array}$ & $\begin{array}{c}\text { Aplikasi } \\
\text { Pemetaan Bumi } \\
\text { dan Program } \\
\text { Pemodelan untuk } \\
\text { Kontur. }\end{array}$ \\
\hline
\end{tabular}

\section{Metode Penelitian}

Penelitian ini dilakukan dengan tahapan seperti yang terlihat pada Gambar 4. Diagram alur penelitian. 


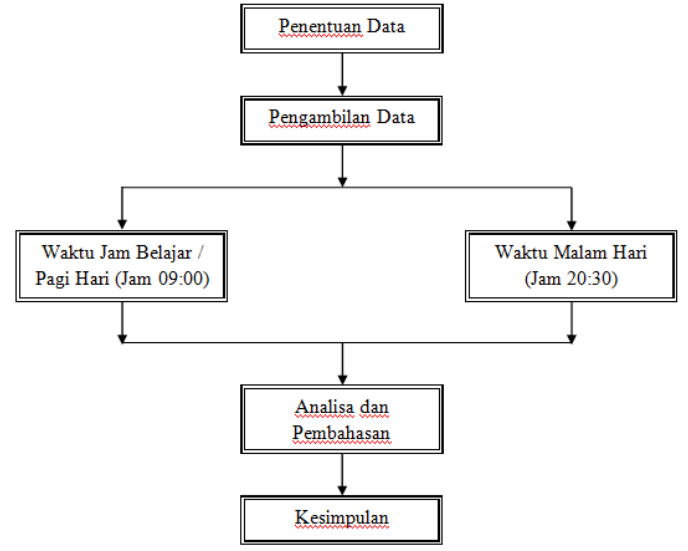

Gambar 4: Diagram Alur Penelitian

\section{Teknik Analisis Data}

Sampel intensitas kebisingan diperoleh dari pengukuran langsung, yaitu Menggunakan alat telepon genggam Smartphone Samsung Galaxy Core Duos i8262 dengan aplikasi Noise Meter 2.5 yang sudah di kalibrasikan dengan Sound Level Meter Mastech MS6300.

Pengumpulan data baik intensitas kebisingan dan jumlah kendaran dilakukan pada dua waktu yaitu di waktu jam belajar pada pukul 09:00 WIB dan malam hari pada pukul 20:30 WIB.

Pengukuran intensistas kebisingan dilakukan setiap 5 detik selama 10 menit. Sedangkan pengukuran jumlah kendaraan dilakukan selama 10 menit. Dengan posisi sampling di dalam Komplek Perguruan Muhammadiyah Kota Pekanbaru seperti terlihat pada Gambar 5 dan Tabel 2.

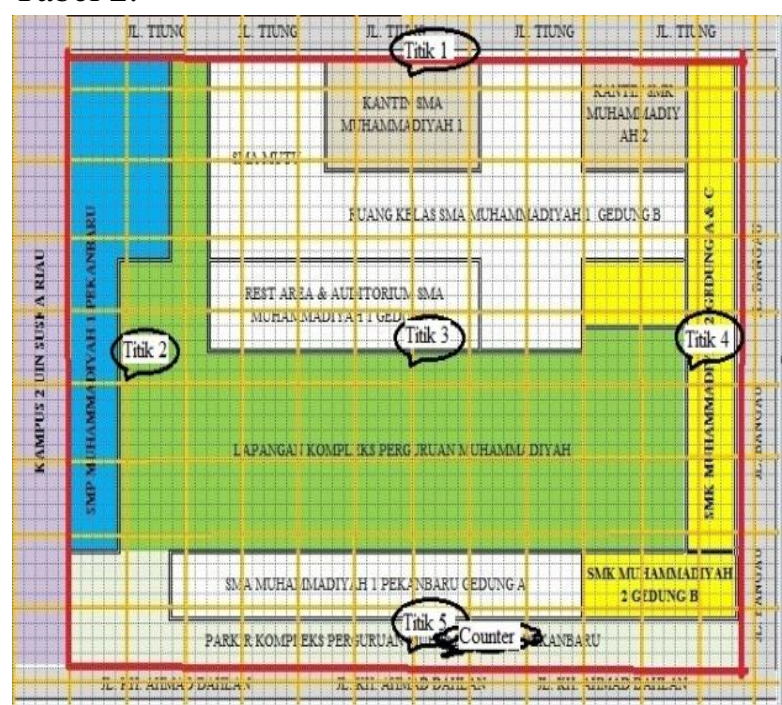

Gambar 5: Lokasi Sampel Pengambilan Titik Kebisingan.
Tabel 2. Titik Koordinat Lokasi Sampling.

\begin{tabular}{|l|c|c|l|}
\hline $\begin{array}{c}\text { Titik } \\
\text { Pengukuran }\end{array}$ & Lintang & Bujur & \multicolumn{1}{|c|}{ Keterangan } \\
\hline \hline Titik 1 & 0,511543 & 101,437069 & $\begin{array}{l}\text { Kantin SMA } \\
\text { Muhammadiyah 1 }\end{array}$ \\
\hline Titik 2 & 0,511367 & 101,437420 & $\begin{array}{l}\text { SMP } \\
\text { Muhammadiyah 1 }\end{array}$ \\
\hline Titik 3 & 0,511558 & 101,437360 & Lapangan Komplek \\
\hline Titik 4 & 0,511914 & 101,437321 & $\begin{array}{l}\text { SMK } \\
\text { Muhammadiyah 2 }\end{array}$ \\
\hline Titik 5 & 0,511717 & 101,437842 & $\begin{array}{l}\text { Parkiran Depan } \\
\text { Komplek }\end{array}$ \\
\hline
\end{tabular}

Data yang diperoleh dan diolah dengan tahapan sebagai berikut:

a. Menghitung tingkat kebisingan sinambung setara $\left(\mathrm{L}_{\mathrm{TM}}\right)$, dengan persamaan sebagai berikut:

$\mathrm{L}_{\mathrm{TM} 5}=10 \log 1 / 600\left\{5 \cdot 10^{0,1 \mathrm{~L} 1}+5 \cdot 10^{0,1 \mathrm{~L} 2}+\right.$ $\left.\ldots+5.10^{0,1 \mathrm{~L} 120}\right\}$

b. Melakukan pemetaan dengan menggunakan Aplikasi Surfer 9 sesuai dengan posisi pengambilan sampel.

c. Menganalisa sumber kebisingan dari lalu lintas jalan raya berdasarkan sebaran tingkat kebisingan pada jam belajar dan malam hari

\section{HASIL DAN PEMBAHASAN}

Komplek Perguruan Muhammadiyah Kota Pekanbaru yang berbatasan langsung dengan:

a. Sebelah utara berbatasan dengan jalan Bangau,

b. Sebelah selatan berbatasan dengan Kampus UIN Sultan Syarif Kasim Sukajadi,

c. Sebelah barat berbatasan dengan jalan Tiung,

d. Sebelah timur berbatasan dengan jalan KH. Ahmad Dahlan.

Selain kegiatan belajar mengajar baik di dalam kelas maupun di lapangan Komplek Perguruan Muhammadiyah Kota Pekanbaru, aktivitas yang berlangsung disekitar komplek berupa lalu lalang kendaran bermotor, aktivitas jual beli koperasi atau kantin dan pedagang disekitar pagar Komplek Perguruan Muhammadiyah Kota Pekanbaru.

Hasil Penelitian

Pengukuran intensitas kebisingan dilakukan pada jam belajar dan pada malam hari dengan lokasi pengukuran seperti yang terlihat pada Gambar 6. 


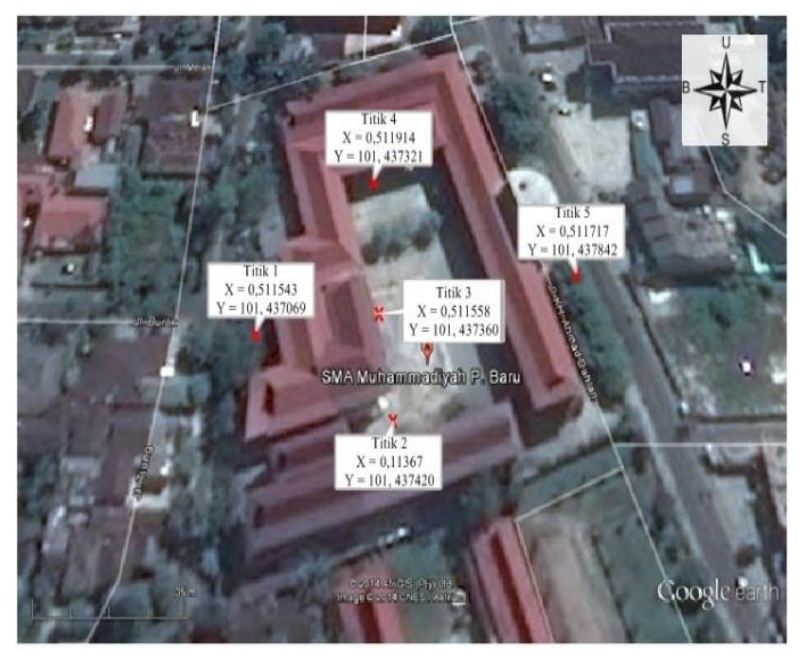

(Sumber: Google Earth, 2014)

Gambar 6. Peta Titik Pesebaran Tingkat Kebisingan di Wilayah Penelitian

Tabel 3. Hasil Pengukuran Tingkat Kebisingan Pada Jam Belajar.

\begin{tabular}{|c|c|}
\hline Titik Pengukuran & Tingkat Kebisingan dB (A) \\
\hline \hline Titik 1 & 61,2 \\
\hline Titik 2 & 67,1 \\
\hline Titik 3 & 68,0 \\
\hline Titik 4 & 64,6 \\
\hline Titik 5 & 69,0 \\
\hline Rata-Rata & 66,0 \\
\hline
\end{tabular}

\section{Pengukuran Pada Jam Belajar}

Pengukuran intensitas kebisingan dilakukan pada jam belajar atau pagi hari di pukul 09:00 WIB. Hasil dari pengukuran tingkat kebisingan pada jam belajar, intensitas kebisingan yang tinggi terjadi pada Titik 5 sebesar $69,0 \mathrm{~dB}$ (A) dan Titik 3 sebesar 68,0 dB (A) (Tabel 4.1), sedangkan tingkat kebisingan terendah terjadi pada Titik 1 sebesar 61,2 dB (A).

Aktivitas yang berlangsung ketika pengukuran adalah kegiatan belajar mengajar di kelas, kegiatan olah raga di lapangan, pedagang di sekitar komplek dan lalu lintas jalan di sekitar Komplek Perguruan Muhammadiyah Kota Pekanbaru.

Berikut ini penjelasan hasil dari pengukuran, yaitu:

a. Pada Titik 1 didapatkan hasil pengukuran intensitas kebisingan sebesar 61,2 dB (A) dimana pada saat pengukuran aktivitas yang berlangsung disekitar lokasi adalah kegiatan belajar mengajar, aktivitas jual beli di kantin/ koperasi dan transportasi darat seperti mobil dan sepeda motor di jalan Tiung.

b. Pada Titik 2 didapatkan hasil pengukuran intensitas kebisingan sebesar 67,1 dB (A) dimana pada saat pengukuran aktivitas yang berlangsung disekitar lokasi adalah aktivitas kegiatan belajar mengajar, suara peserta didik itu sendiri, kegiatan olah raga dilapangan dan alat transportasi darat seperti mobil, sepeda motor dan angkutan umum.

c. Titik 3 didapatkan hasil pengukuran intensitas kebisingan sebesar 68,0 dB (A) dimana pada saat pengukuran aktivitas yang berlangsung disekitar lokasi adalah kegiatan belajar mengajar, kegiatan olah raga dilapangan dan alat transportasi darat seperti mobil, sepeda motor dan angkutan umum.

d. Titik 4 didapatkan hasil pengukuran intensitas kebisingan sebesar 64,6 dB (A) dimana pada saat pengukuran aktivitas yang berlangsung disekitar lokasi adalah kegiatan belajar mengajar, jual beli di kantin atau koperasi dan aktivitas jalan Bangau serta alat transportasi darat.

e. Titik 5 didapatkan hasil pengukuran intensitas kebisingan sebesar 69,0 dB (A) dimana pada saat pengukuran aktivitas yang berlangsung disekitar lokasi adalah alat tranportasi darat seperti mobil, sepeda motor dan angkutan umum dengan volume kendaraan 374 kendaran yang terdiri dari sepeda motor sebanyak 279 kendaran dan mobil sebanyak 95 kendaran dan aktivitas pedang kaki lima di pinggir jalan.

Sedangkan perhitungan volume kendaran yang melintas di jalan KH. Ahmad Dahlan.Volume kendaran yang melintasi jalan KH. Ahmad Dahlan adalah sebanyak 374 kendaran.

\section{Pengukuran Pada Malam Hari}

Pengukuran ini dilakukan pada malam hari (Pukul 20:30 WIB), selain pengukuran tingkat kebisingan juga dilakukan pengukuran volume 
kendaran yang melintas di jalan KH. Ahmad Dahlan.

Aktivitas yang berlangsung ketika pengukuran adalah lalu lintas jalan di sekitar Komplek Perguruan Muhammadiyah Kota Pekanbaru.

Hasil dari pengukuran tingkat kebisingan pada malam hari, intensitas kebisingan yang tinggi terjadi pada Titik 4 sebesar $54,1 \mathrm{~dB}$ (A) dan Titik 5 sebesar 53,7 dB (A) (Tabel 4.2), sedangkan tingkat kebisingan terendah terjadi pada Titik 1 sebesar 50,1 dB (A). Volume kendaran yang melintasi jalan KH. Ahmad Dahlan adalah 327 kendaran.

Tabel 4. Hasil Pengukuran Tingkat Kebisingan Pada Malam Hari.

\begin{tabular}{|c|c|}
\hline Titik Pengukuran & Tingkat Kebisingan dB (A) \\
\hline \hline Titik 1 & 50,1 \\
\hline Titik 2 & 51,1 \\
\hline Titik 3 & 52,8 \\
\hline Titik 4 & 54,1 \\
\hline Titik 5 & 53,7 \\
\hline Rata-Rata & 52,4 \\
\hline
\end{tabular}

Berikut ini penjelasan hasil dari pengukuran, yaitu:

a. Titik 1 didapatkan hasil pengukuran intensitas kebisingan sebesar 50,1 $\mathrm{dB}(\mathrm{A})$ dimana pada saat pengukuran aktivitas yang berlangsung disekitar lokasi adalah alat transportasi darat.

b. Titik 2 didapatkan hasil pengukuran intensitas kebisingan sebesar 51,5 $\mathrm{dB}(\mathrm{A})$ dimana pada saat pengukuran aktivitas yang berlangsung disekitar lokasi adalah aktivitas gedung seperti kipas $\mathrm{AC}$, alat transportasi darat seperti mobil, sepeda motor serta angkutan umum.

c. Titik 3 didapatkan hasil pengukuran intensitas kebisingan sebesar 52,8 $\mathrm{dB}(\mathrm{A})$ dimana pada saat pengukuran aktivitas yang berlangsung disekitar lokasi adalah alat transportasi darat seperti mobil, sepeda motor serta angkutan umum. d. Titik 4 didapatkan hasil pengukuran intensitas kebisingan sebesar 54,1 dB(A) dimana pada saat pengukuran aktivitas yang berlangsung disekitar lokasi adalah aktivitas jalan Bangau dan alat transportasi darat.

e. Titik 5 didapatkan hasil pengukuran intensitas kebisingan sebesar 53,7 dB(A) dimana pada saat pengukuran aktivitas yang berlangsung disekitar lokasi adalah alat tranportasi darat seperti mobil, sepeda motor dan angkutan umum dengan volume kendaraan 327 kendaran yang terdiri dari sepeda motor sebanyak 267 kendaran dan mobil sebanyak 60 kendaran.

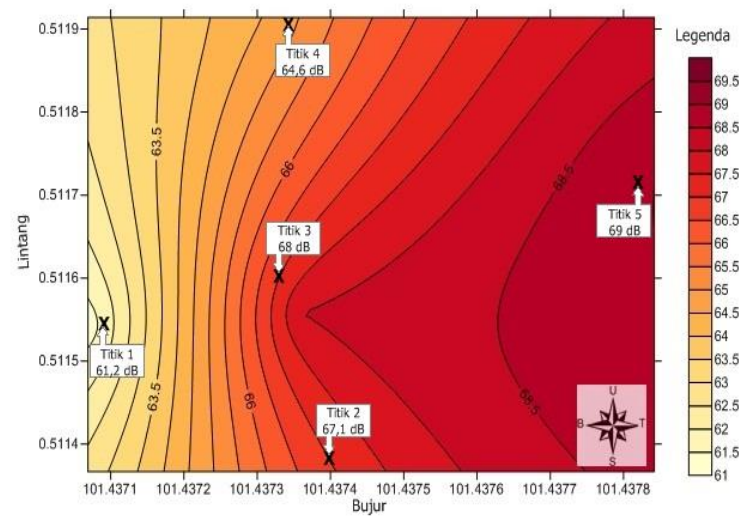

Gambar 7. Peta Titik Pesebaran Intensitas Kebisingan Pada Jam Belajar

Intensitas kebisingan pada waktu jam belajar Hasil dari pengukuran intensitas kebisingan pada jam belajar diperoleh sebaran intensitas kebisingan seperti pada Gambar 7 yang menunjukan bahwa sebaran kebisingan tertinggi menyebar dari Timur menuju ke Barat lokasi penelitian. Sebelah Timur lokasi penelitian adalah Komplek Perguruan Muhammadiyah Kota Pekanbaru berbatasan langsung dengan jalan KH. Ahmad Dahlan (Pengukuran Titik 5). Intensitas kebisingan pada lokasi tersebut adalah $69 \mathrm{~dB}(\mathrm{~A})$ yang bersumber dari suara lalu lintas kendaraan.

Berdasarkan persamaan 2.7, dapat diketahui sebaran intensitas kebisingan dari lalu lintas jalan raya (titik 5). Hasil perhitungan diperoleh kebisingan pada titik 1 yang berjarak $80 \mathrm{~m}$ dari titik 5 sebesar $51,7 \mathrm{~dB}(\mathrm{~A})$, titik 2 dan titik 3 yang berjarak $56 \mathrm{~m}$ dari titik 5 sebesar 38,2 $\mathrm{dB}(\mathrm{A})$, dan pada titik 4 yang berjarak 54 dari 
titik 5 sebesar 38,9 dB(A). Persamaan ini masih belum memasukkan faktor ke beradaan bangunan di Komplek Perguruan Muhammadiyah Kota Pekanbaru. Keberadaan bangunan di sekitar komplek dapat mempengaruhi intensitas kebisingan. Efektivitas bangunan yang terbuat dari batu bata memiliki efektivitas pengurangan sebesar 15-16 dB (A) (sumber Pedomoman Mitigasi Dampak Kebisingan PU, 2004), sehingga nilai efektifitas kebisingan pada titik 1 sebesar $36,7 \mathrm{~dB}(\mathrm{~A})$, titik 2 dan titik 3 sebesar $38,2 \mathrm{~dB}(\mathrm{~A})$ dan pada titik 4 sebesar 38,9 dB(A).

Perbandingan antara hasil perhitungan sebaran intensitas kebisingan yang bersumber dari lalu lintas jalan raya dan hasil pengukuran (Tabel 5) menunjukkan bahwa sumber kebisingan tidak hanya disebabkan aktivitas lalu lintas jalan raya KH. Ahmad Dahlan tetapi juga dipengaruhi oleh sumber lain seperti aktivitas belajar di dalam dan diluar kelas, aktivitas jual beli dan lalu lintas jalan Bangau dan jalan Tiung.

Tabel 5 Perbandingan Intensitas Kebisingan Hasil Perhitungan Sebaran Kebisingan Jalan KH. Ahmad Dahlan dengan Hasil Pengukuran Pada Waktu Jam Belajar

\begin{tabular}{|c|c|c|}
\hline Titik & Perhitungan dB (A) & $\begin{array}{c}\text { Pengukuran } \\
\text { dB (A) }\end{array}$ \\
\hline \hline Titik 1 & 36,7 & 61,2 \\
\hline Titik 2 & 38,2 & 67,1 \\
\hline Titik 3 & 38,2 & 68 \\
\hline Titik 4 & 38,9 & 64,6 \\
\hline
\end{tabular}

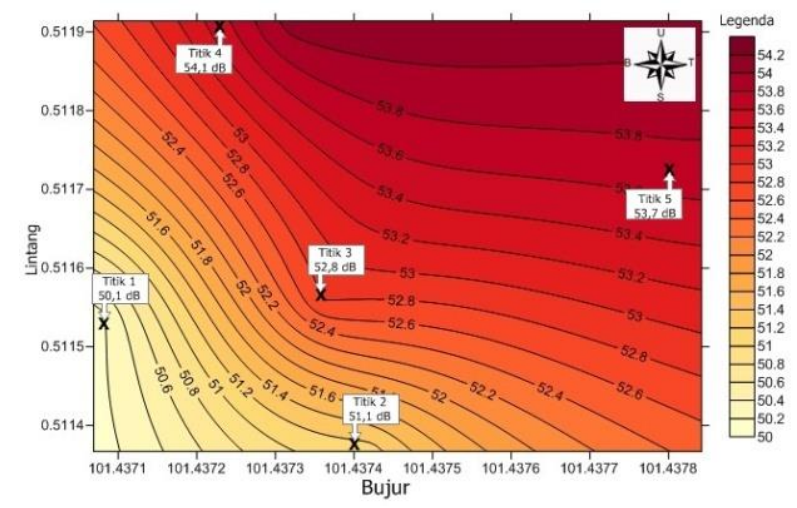

Gambar 8. Peta Titik Pesebaran Intensitas Kebisingan Pada Waktu Malam Hari.
Intensitas kebisingan pada waktu malam hari

Hasil dari pengukuran intensitas kebisingan pada malam hari diperoleh sebaran pemetaan intensitas kebisingan seperti pada Gambar 4.3 yang menunjukan bahwa sebaran kebisingan tertinggi menyebar dari timur laut menuju ke barat daya lokasi penelitian. Sebelah timur laut lokasi penelitian adalah Komplek Perguruan Muhammadiyah Kota Pekanbaru berbatasan langsung dengan jalan Bangau (Pengukuran Titik 4). Intensitas kebisingan pada lokasi tersebut adalah $54,1 \mathrm{~dB}(\mathrm{~A})$ yang bersumber dari suara lalu lintas kendaraan dan akan menyebar ke arah barat daya.

Berdasarkan persamaan 2.7, dapat diketahui sebaran intensitas kebisingan dari lalu lintas jalan raya (titik 5). Hasil perhitungan diperoleh kebisingan pada titik 1 yang berjarak $80 \mathrm{~m}$ dari titik 5 sebesar $36,4 \mathrm{~dB}(\mathrm{~A})$, titik 2 dan titik 3 yang berjarak $56 \mathrm{~m}$ dari titik 5 sebesar 37,9 $\mathrm{dB}(\mathrm{A})$, dan pada titik 4 yang berjarak 54 dari titik 5 sebesar 38,6 dB(A). Persamaan ini masih belum memasukkan faktor ke beradaan bangunan di Komplek Perguruan Muhammadiyah Kota Pekanbaru. Keberadaan bangunan di sekitar komplek dapat mempengaruhi intensitas kebisingan. Efektivitas bangunan yang terbuat dari batu bata memiliki efektivitas pengurangan sebesar 15-16 dB (A) (sumber Pedomoman Mitigasi Dampak Kebisingan PU, 2004), sehingga nilai efektifitas kebisingan pada titik 1 sebesar 21,4 dB(A), titik 2 dan titik 3 sebesar 22,9 $\mathrm{dB}(\mathrm{A})$ dan pada titik 4 sebesar 21,6 dB(A).

Perbandingan antara hasil perhitungan sebaran intensitas kebisingan yang bersumber dari lalu lintas jalan raya dan hasil pengukuran (Tabel 5) menunjukkan bahwa sumber kebisingan tidak hanya disebabkan aktivitas lalu lintas jalan raya KH. Ahmad Dahlan tetapi juga dipengaruhi oleh sumber lain seperti bunyi hewan (jangkrik dan cicak) dan lalu lintas jalan Bangau dan jalan Tiung.

Tabel 6 Perbandingan Intensitas Kebisingan Hasil Perhitungan Sebaran Kebisingan Jalan KH. Ahmad 
Dahlan dengan Hasil Pengukuran Pada Waktu Malam Hari.

\begin{tabular}{|c|c|c|}
\hline Titik & Perhitungan dB (A) & $\begin{array}{c}\text { Pengukuran } \\
\mathrm{dB}(\mathrm{A})\end{array}$ \\
\hline \hline Titik 1 & 21,4 & 50,1 \\
\hline Titik 2 & 22,9 & 51,1 \\
\hline Titik 3 & 22,9 & 52,8 \\
\hline Titik 4 & 21,6 & 54,1 \\
\hline
\end{tabular}

Dari Tabel 5 dan Tabel 6, menunjukan bahwa sumber kebisingan dari jalan KH. Ahmad Dahlan yang menyebar pada area Komplek Perguruan Muhammadiyah lebih kecil dari hasil pengukuran. Namun intensitas pada area yang dekat dengan aktivitas jalan raya memiliki intensitas yang paling tinggi seperti yang terlihat pada Gambar 7 dan Gambar 8.

Hasil pengukuran intensitas kebisingan pada waktu jam belajar rata-rata $66 \mathrm{~dB}$ (A) nilai tersebut berada diatas Nilai Baku kebisingan untuk lokasi pendidikan ( $55 \mathrm{~dB}(\mathrm{~A})$ ), yang akan menimbulkan rasa ketidaknyamanan pada peserta didik saat mengikuti kegiatan belajar mengajar.

Hasil penelitian ini membuktikan pada penelitan sebelumnya tentang tinjauan hubungan kebisingan dan keluhan pada peserta didik SMA Muhammadiyah 1 Pekanbaru. Dimana 353 responden diperoleh hasil bahwa $27 \%$ responden sangat terganggu akibat kebisingan, $64 \%$ terganggu dan hanya $9 \%$ yang tidak terganggu akibat kebisingan, nilai tersebut menunjukan bahwa mayoritas responden mengatakan lingkungan Perguruan Muhammadiyah dalam kondisi bising. Jika digabungkan antara responden yang mengalami gangguan dengan yang sangat mengalami gangguan akibat kebisingan adalah sebesar $91 \%$. Sehingga dapat dikatakan bahwa lingkungan Perguruan Muhammadiyah dalam kondisi yang tidak nyaman untuk proses belajar mengajar.

Kondisi bising yang dialami oleh peserta didik akan berdampak pada gangguan-gangguan lainnya, seperti gangguan konsentrasi dan gangguan komunikasi. Dampak kebisingan tersebut berdampak pada proses belajar mengajar, dimana fokus pengambilan data adalah apakah dampak yang timbulkan akibat kebisingan terhadap faktor komunikasi, hasilnya adalah dari 353 responden yang sama mengatakan bahwa $21 \%$ sangat mengalami gangguan komunikasi, $57 \%$ mengalami gangguan komunikasi dan $22 \%$ mengganggap kebisingan tidak mengganggu komunikasi.

\section{KESIMPULAN}

Berdasarkan hasil pembahasan yang telah dilakukan, dapat disimpulkan:

1. Tingkat kebisingan di hari kerja atau di jam sekolah di Komplek Perguruan Muhammadiyah Kota Pekanbaru kebisingan tertinggi adalah Titik 5 sebesar $69 \mathrm{~dB}$ (A) dan terendah adalah Titik 1 sebesar 61,2 dB (A) dengan rata-rata tingkat kebisingan adalah $66 \mathrm{~dB}(\mathrm{~A})$.

2. Tingkat kebisingan di malam hari di Komplek Perguruan Muhammadiyah Kota Pekanbaru kebisingan tertinggi adalah Titik 4 sebesar 54,1 dB (A) dan terendah adalah Titik 1 sebesar 50,1 dB (A) dengan ratarata tingkat kebisingan adalah 52,4 dB (A).

3. Dari analisis peredaran tingkat kebisingan pada wilayah studi yang dihasilkan oleh program Surfer 9 pada jam belajar adalah hasil dari pemetaan intensitas kebisingan menunjukan bahwa sebaran kebisingan tertinggi menyebar dari timur menuju ke barat lokasi penelitian, sedangkan pada malam hari menunjukan bahwa sebaran kebisingan tertinggi menyebar dari timur laut menuju ke barat daya lokasi penelitian.

4. Faktor-faktor yang mempengaruhi kebisingan di dalam Komplek Perguruan Muhammadiyah Kota Pekanbaru adalah kegiatan belajar mengajar itu sendiri dan alat transportasi darat yang paling besar mempengaruhi tingkat kebisingan antara lain mobil, sepeda motor dan angkutan umum

\section{DAFTAR PUSTAKA}

Azwar, Azrul. 1995. Pengantar Ilmu Kesehatan Lingkungan. Mutiara Sumber Widya. Jakarta.

Departemen Kesehatan RI. 1993. Kebijakan Teknis Pengawasan Kualitas Lingkungan 
Dalam Rangka Pelaksanaan Program PLP. Jakarta.

Dirjen P2M, PLP. 1994/ 1995. Petunjuk Pelaksanaan Pengawasan Kebisingan. Jakarta.

Doelle Leslie L, 1993. Akustik Lingkungan, Erlangga. Jakarta.

Edy Syahrial. 2001. Dasar-Dasar Pendidikan Kesehatan dan Ilmu Perilaku. FKM USU. Medan.

Gunarwan, F. 1992. Analisa Mengenai Dampak Lingkungan. Gajah Mada University. Yogyakarta.

Justian, Alex. 2012. Analisis Pengaruh Kebisingan Terhadap Performa Siswa Sekolah Dasar Diruang Kelas. FT Universitas Indonesia. Depok.

Kementrian Lingkungan Hidup. 2002. Himpunan Peraturan Perundang-undangan di Bidang Pengelolaan dan Pengendalian Dampak Lingkungan Era Otonomi Daerah. Jakarta.

Keputusan Menteri Lingkungan Hidup Nomor 48 Tahun 1996 Tentang Baku Tingkat
Kebisingan. Jakarta.

Noname. 2011. Pengertian Sekolah. [Online]. Tersedia: http://lenterakecil.com/pengertiansekolah/, Accesed on Januari 23th 2014.

Noname. 2012. Karakteristik Sekolah Menengah Umum.

Tersedia:

http://himitsuqalbu.wordpress.com/2012/03/ 08/karakteristik-sekolah-menengah-umum/.

Accesed on Januari 24th 2014.

Notoatmodjo, Soekidjo. 1997. Ilmu Kesehatan Masyarakat. Rinika Cipta. Jakarta.

Slamet, J., S. 1996. Kesehatan Lingkungan. Gajah Mada University Press. Yogyakarta.

Soedjono. 1990-1991. Pengawasan Pencemaran Lingkungan Fisik, Dep. Kes. RI., Jakarta.

Suma'mur, 1998. Hygiene Perusahaan dan Kesehatan Kerja. Jakarta.

Syafridah, L. 2005. Pengukuran Tingkat Kebisingan Pada Sekolah Dasar Negeri yang Berada Ditepi Jalan dan Yang Tidak Berada Ditepi Jalan Di Kecamatan Medan Perjuangan Kota Medan, Universitas Sumatera Utara, Medan. 